\title{
Development and production of iceberg lettuce irrigated with magnetically treated water
}

\author{
Lis Tavares Ordones Lemos' (iD, Fábio Ponciano de Deus', Valter Carvalho de Andrade Júnior², Michael Silveira Thebaldi' (iD, \\ Marcio Mesquita ${ }^{3}$ and Rodrigo César de Almeida ${ }^{1}$
}

'Department of Water Resources, Universidade Federal de Lavras, PO Box 3037, Lavras - MG, 37200-900, Brazil

${ }^{2}$ Department of Agriculture, Universidade Federal de Lavras, PO Box 3037, Lavras - MG, 37200-900, Brazil

${ }^{3}$ Agronomy School, Universidade Federal de Goiás, Campus Samambaia, Av. Esperança s/n, Goiânia - Goiás, 74.690-900, Brazil

Irrigated agriculture has become a concern, given the scarcity of freshwater. To reduce its water consumption, new techniques and technologies have been proposed. Based on this, the objective of this work was to evaluate the influence of different soil water tensions at initiation of irrigation with magnetically treated water, on 'iceberg' lettuce Lucy Brown (Lactuca Sativa L.) development and production. The experiment was conducted in a greenhouse, using a completely randomized factorial design, to evaluate two water types (magnetically treated water - MW and ordinary water - OW) and four soil water tensions at initiation of irrigation ( $\mathrm{T} 1-15 \mathrm{kPa}, \mathrm{T} 2-25 \mathrm{kPa}, \mathrm{T} 3-40 \mathrm{kPa}$ and $\mathrm{T} 4-70 \mathrm{kPa}$ ), with three replicates. Tensiometers were used to estimate soil water tension. The evaluated parameters were: aerial part fresh and dry total mass; commercial head fresh and dry mass, root fresh and dry mass; stem fresh and dry mass; stem length and diameter; percentage of leaves with tip burn, total and commercial yield; water use efficiency related to total and commercial yield; plant exposed area; and dry matter content. Despite achieving greater water use efficiency, the magnetic treatment may have hindered the removal of water from the soil by the crop, especially at increased soil water tension at initiation of irrigation.

\section{INTRODUCTION}

The increase in water use efficiency in irrigated agriculture has become one of the main objectives of many research investigations (Valnir Júnior et al., 2017). These studies, beyond aiming to positively impact the economy, aim to enable cultivation and food security in water-stressed locations. In this regard, companies in the sector have also invested in the development of techniques and technologies to reduce water consumption, while maintaining or increasing production.

Use of water subjected to magnetic treatment in irrigated agriculture has been investigated, with productive and qualitative benefits in production having been observed, in addition to saving water and increasing the efficiency of water use and fertilizers. Most of these studies took place in developing countries, such as Nigeria, Pakistan, India, and Brazil, among others, and were aimed at enabling irrigated cultivation in environments with problems of water availability (Adeniran et al., 2020; Al-Said et al., 2018; Surendran et al., 2016; Pradela et al., 2018).

As an example of water saving, in some studies it was observed that when using magnetically treated irrigation water, the soil moisture and water tension was maintained for a longer time (Surendran et al., 2016; Lemos et al., 2021). According to Mostafazadeh-Fard et al. (2011), this could possibly be explained by the increase in soil osmotic pressure. Additionally, the authors comment that modification of the structure of the water clusters makes the water more cohesive; therefore, water molecules can easily attach to soil particles and penetrate into micropores, increasing water retention by the medium.

According to some authors, magnetic treatment causes physical and chemical changes to the water (Pang and Deng, 2008; Toledo et al., 2008; Cai et al., 2009; Mostafazadeh-Fard et al., 2011; Pang et al., 2012; Khoshravesh-Miangoleh and Kiani, 2014; Surendran et al., 2016; Wang et al., 2018). The following were observed: decrease in internal hydrogen bonds of water clusters, decrease in size [of what?] and strengthening of bonds between clusters; decreased contact angle between water and surfaces; decreased surface tension; decreased hydrophobicity of different materials; increased viscosity; decreased specific heat; increased dielectric constant; and increased electrical conductivity.

For lettuce cultivation, irrigation is an important technique, and the use of magnetically treated water has the potential to create economic benefits due to the high cultivation water demand of lettuce (Geisenhoff et al., 2016; Baudoin et al., 2017). Lettuce is a crop that offers macro- and micro-nutrients essential to the human diet, being one of the most produced and consumed leafy vegetables in the world (Hotta, 2008; Geisenhoff et al., 2016; Baudoin et al., 2017; Urbano et al., 2017). For example, in 2017, Brazilian lettuce production was 671.5 thousand tons, representing $50 \%$ of the area of all vegetable production, with the iceberg variety ranking second in importance among the types of lettuce (Kist et al., 2020).

Some studies have evaluated the use of magnetically treated water in the irrigated cultivation of lettuce. Putti et al. (2015b), using magnetically treated water for lettuce irrigation, found an increase of $63 \%$ in the fresh weight of the commercial head of iceberg lettuce, with a reduction in the applied

\section{CORRESPONDENCE}

Michael Silveira Thebaldi

\section{EMAIL}

michael.thebaldi@ufla.br

\section{DATES}

Received: 14 October 2020

Accepted: 24 September 2021

\section{KEYWORDS}

agricultural water soil water tension tensiometry crop yield

\section{COPYRIGHT}

() The Author(s)

Published under a Creative Commons Attribution 4.0 International Licence (CC BY 4.0) 
water volume, as well as a reduction in the crop cycle, increasing water use efficiency. Pradela et al. (2018) observed a dry weight increase in total aerial parts (11.02\%) and roots (12.09\%) of iceberg lettuce seedlings irrigated with magnetically treated water.

Despite several studies pointing to the productive and watersaving benefits of magnetic treatment of water for irrigated agriculture, there is still a need for more scientific evaluation of this treatment's effectiveness under different edaphoclimatic conditions. This is needed to establish the security of investments in this technology, even more so when made by farmers in developing countries and with water availability challenges.

Thus, the objective of this work was to evaluate the influence of different soil water tensions at the initiation of irrigation with magnetically treated water on iceberg lettuce Lucy Brown (Lactuca sativa L.) development and production.

\section{METHODS}

\section{Study site}

The experiment was conducted in a greenhouse $(7 \times 30 \mathrm{~m}$ in size, with transparent $150 \mu \mathrm{m}$ plastic with anti-UV additive on the top, and anti-aphid screen on the sides), in the south of Minas Gerais, Brazil $\left(21^{\circ} 14^{\prime} \mathrm{S}, 45^{\circ} 00^{\prime} \mathrm{W}\right.$ and $910 \mathrm{~m}$ amsl). According to the Köppen-Geiger classification, the region's climate is Cwa (subtropical climate with dry winter, temperatures below $18^{\circ} \mathrm{C}$, and hot summer, with temperatures above $22^{\circ} \mathrm{C}$ ), with a mean annual air temperature of $20.4^{\circ} \mathrm{C}$ and mean annual precipitation of $1460 \mathrm{~mm}$ (Alvares et al., 2013).

During the experiment, the air temperature and relative humidity were monitored with a digital thermohygrometer (model HT-600, from Instrutherm), installed in a meteorological shelter inside the greenhouse ( $2 \mathrm{~m}$ above ground level). In addition, water evaporation was monitored inside the greenhouse with a minievaporimeter (cylindrical stainless-steel container with $60 \mathrm{~cm}$ in diameter and $25 \mathrm{~cm}$ high).

The soil of the experimental area was classified as Typic Hapludox (Soil Survey Staff, 1999). Table 1 shows the results of the chemical and physical analyses of the soil, referring to the depths of 0 to 20 $\mathrm{cm}$ and 20 to $40 \mathrm{~cm}$.

\section{Crop implantation}

Lettuce cultivar Lucy Brown (Lactuca sativa L.) seedlings were transplanted into 24 manually constructed beds (bed area (A) of $2.88 \mathrm{~m}^{2}$, equivalent to $\left.1.2 \times 2.4 \mathrm{~m}\right), 23$ days after sowing, at a spacing of $0.30 \times 0.30 \mathrm{~m}$ ( 32 plants per bed).

The crop planting and cover fertilizations were the same for all beds, and carried out based on the results of the chemical analysis of the soil, following recommendations of Ribeiro et al. (1999).

For planting, $30 \mathrm{t} \cdot \mathrm{ha}^{-1}$ of manure $\left(8.64 \mathrm{~kg} \cdot \mathrm{bed}^{-1}\right)$ and $1 \mathrm{t} \cdot \mathrm{ha}^{-1}$ of NPK fertilizer (4-30-10 ratio, $0.288 \mathrm{~kg}$ per bed) were used. The cover fertilization was carried out 10 and 20 days after transplanting, applying $30 \mathrm{~g} \cdot \mathrm{m}^{-2}$ of ammonium sulfate $\left(86.4 \mathrm{~g} \cdot \mathrm{bed}^{-1}\right)$ and $5 \mathrm{~g} \cdot \mathrm{m}^{-2}$ of potassium chloride (14.4 $\mathrm{g}$ per bed).

In order to guarantee the survival of the seedlings after transplanting, as well as to standardize the size of the plants, daily irrigation was carried out for 8 days after transplanting, in order to maintain the soil moisture at the field capacity. The total irrigation depth at this phase was $15.85 \mathrm{~mm}$ (average $1.98 \mathrm{~mm} \cdot \mathrm{d}^{-1}$ ).

\section{Experimental design and treatments}

The experimental design was completely randomized, in a factorial $2 \times 4$, with 3 replications (R1, R2 and R3). The treatments
Table 1. Chemical and physical soil analysis results from the experimental area soil, referring to the depths of 0 to $20 \mathrm{~cm}$ and 20 to $40 \mathrm{~cm}^{1}$

\begin{tabular}{|c|c|c|}
\hline \multirow[t]{2}{*}{ Parameter (unit) } & \multicolumn{2}{|c|}{ Depth $(\mathrm{cm})$} \\
\hline & $0-20$ & $20-40$ \\
\hline $\mathrm{pH}$ & 6.60 & 6.40 \\
\hline $\mathrm{K}\left(\mathrm{mg} \cdot \mathrm{dm}^{-3}\right)$ & 87.00 & 39.22 \\
\hline$P\left(\mathrm{mg} \cdot \mathrm{dm}^{-3}\right)$ & 10.03 & 4.89 \\
\hline $\mathrm{Ca}\left(\mathrm{cmolc} \cdot \mathrm{dm}^{-3}\right)$ & 4.82 & 4.16 \\
\hline $\mathrm{Mg}\left(\mathrm{cmolc} \cdot \mathrm{dm}^{-3}\right)$ & 2.10 & 1.83 \\
\hline $\mathrm{Al}\left(\mathrm{cmolc} \cdot \mathrm{dm}^{-3}\right)$ & 0.04 & 0.04 \\
\hline $\mathrm{H}+\mathrm{Al}\left(\mathrm{cmolc} \cdot \mathrm{dm}^{-3}\right)$ & 1.03 & 1.10 \\
\hline $\mathrm{SB}\left(\mathrm{cmolc} \cdot \mathrm{dm}^{-3}\right)$ & 7.14 & 6.09 \\
\hline$t\left(\mathrm{cmolc} \cdot \mathrm{dm}^{-3}\right)$ & 7.18 & 6.13 \\
\hline$T\left(\mathrm{cmolc} \cdot \mathrm{dm}^{-3}\right)$ & 8.17 & 7.19 \\
\hline$V(\%)$ & 87.43 & 84.71 \\
\hline$m(\%)$ & 0.56 & 0.65 \\
\hline M.O. (dag $\left.\cdot \mathrm{kg}^{-1}\right)$ & 2.96 & 2.39 \\
\hline P-Rem $\left(\mathrm{mg} \cdot \mathrm{L}^{-1}\right)$ & 67.10 & 67.70 \\
\hline $\mathrm{Zn}\left(\mathrm{mg} \cdot \mathrm{dm}^{-3}\right)$ & 2.98 & 1.79 \\
\hline $\mathrm{Fe}\left(\mathrm{mg} \cdot \mathrm{dm}^{-3}\right)$ & 63.13 & 57.76 \\
\hline$M n\left(m g \cdot d^{-3}\right)$ & 85.78 & 68.12 \\
\hline $\mathrm{Cu}\left(\mathrm{mg} \cdot \mathrm{dm}^{-3}\right)$ & 5.46 & 5.27 \\
\hline$B\left(m g \cdot d m^{-3}\right)$ & 0.28 & 0.27 \\
\hline $\mathrm{S}\left(\mathrm{mg} \cdot \mathrm{dm}^{-3}\right)$ & 64.37 & 61.33 \\
\hline Sand (\%) & 10 & \\
\hline Silt (\%) & 29 & \\
\hline Clay (\%) & 61 & \\
\hline$\rho_{\mathrm{s}}\left(\mathrm{g} \cdot \mathrm{cm}^{-3}\right)$ & 1.14 & \\
\hline
\end{tabular}

${ }^{1} \mathrm{~K}$ - potassium; $\mathrm{P}$ - phosphorus; Ca - calcium; Mg - magnesium; Al-aluminium; $H+A l$ - potential acidity with SMP extractor; SB - sum of exchangeable base; $\mathrm{t}$ - effective cation exchange capacity; $\mathrm{T}$ - cation exchange capacity at $\mathrm{pH}$ 7.0; $\mathrm{V}$ - base saturation index; $\mathrm{m}$ - aluminium saturation index; M.O. - organic matter; P-Rem - remaining phosphorus; $\mathrm{Zn}$ - zinc; $\mathrm{Mn}$ - manganese; $\mathrm{Cu}$ - copper; $B$ - boron; $S$ - sulfur; $\rho_{\mathrm{s}}-$ soil bulk density

consisted of the two types of water (magnetically treated water MW; and ordinary water - OW) and four soil water tensions to start irrigation (T1 - $15 \mathrm{kPa}, \mathrm{T} 2-25 \mathrm{kPa}, \mathrm{T} 3-40 \mathrm{kPa}$ and $\mathrm{T} 4-70$ $\mathrm{kPa})$ combinations.

Figure $1 \mathrm{~A}$ shows the treatment distribution in the experimental area, as well as the location of tensiometers used in irrigation management. Figure 1B presents the details of the equipment distribution in the beds, and the designation of the useful plot (8 plants) and the border plants. Each bed had 32 plants $\left(n_{\mathrm{p}}\right)$.

The Sylocimol Residential Magnetizer was used for the water treatment. This equipment is composed of alternating magnets that subject the water to a $3860 \mathrm{G}$ magnetic field, with the capacity to magnetize $1000 \mathrm{~L}$ in $1 \mathrm{~h}$ of exposure. The equipment was located and kept inside a $500 \mathrm{~L}$ water tank throughout the experiment. The soil water tension treatments were related to values for initiation of irrigation, with sufficient water depth to raise the soil moisture to field capacity. The water was collected from an earth dam reservoir close to the experimental area. 


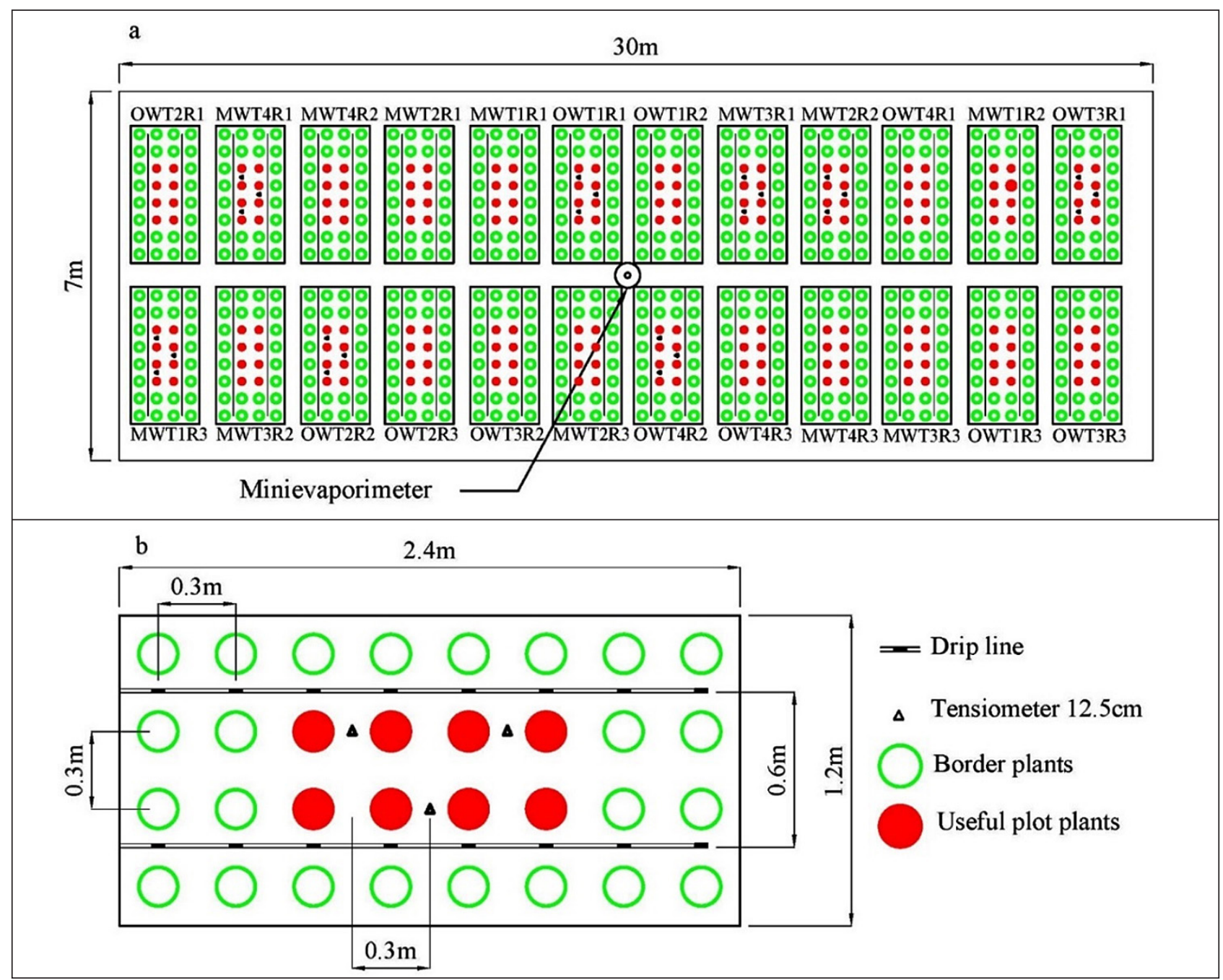

Figure 1. (a) Treatment distribution in the experimental area and location of tensiometers. (b) Details of the equipment distribution in the beds, and designation of the useful plot (8 plants) and the border plants

\section{Irrigation management and experimental conduction}

The soil water retention curve used was generated from data from in-situ evaluation, following recommendations by Jabro et. (2009), carried out in the experimental area (Eq. 1).

$$
\theta_{l}=0.44554-0.04528 \ln \left(\left|\Psi_{\mathrm{m}}\right|\right)
$$

where $\theta_{1}$ is the volumetric soil moisture $\left(\mathrm{cm}^{3 \cdot} \mathrm{cm}^{-3}\right)$, and $\Psi_{\mathrm{m}}$ is the soil water tension or matric potential $(\mathrm{kPa})$.

The soil water tension (retention of water by solid soil surfaces) was estimated by Eq. 2 using the average readings (L) of 3 tensiometers for each treatment. Tensiometers were installed at $0.125 \mathrm{~m}$ depth. This depth corresponds to half of the 'iceberg' lettuce crop effective root depth $(z=25 \mathrm{~cm})$ (Murakami et al., 2002; Yuri et al., 2002). The water column height inside the tensiometers (h) was $22.5 \mathrm{~cm}$.

$$
\Psi_{\mathrm{m}}=L-0.098 \cdot h
$$

where $L$ is the average tensiometer reading $(\mathrm{kPa})$, and $h$ is the water column height inside the tensiometers $(\mathrm{cm})$.

Tensiometer readings were performed twice a day (9:00 and 15:00), with a digital tensimeter (Hidrodinâmica Irrigation). Estimation of net irrigation depth (LL) was made using Eq. 3:

$$
\mathrm{LL}=\left(\theta_{c c}-\theta_{l}\right) \cdot z
$$

where LL is the net irrigation depth $(\mathrm{mm}), \theta_{\mathrm{cc}}$ is the volumetric soil moisture at field capacity $\left(\mathrm{cm}^{3} \cdot \mathrm{cm}^{-3}\right)$, and $z$ is the lettuce effective root depth $(\mathrm{mm})$.

The soil of the experimental area had volumetric moisture and soil water tension at field capacity equal to $0.341 \mathrm{~cm}^{3} \cdot \mathrm{cm}^{-3}$ and $10 \mathrm{kPa}$, respectively. This information was used to carry out irrigation management for the experiment, where a drip system was used (95.4\% irrigation system uniformity of distribution UD), composed of ClickTif NaanDanJain pressure-compensating emitters (average flow - qa, of $2.14 \pm 0.08 \mathrm{~L} \cdot \mathrm{h}^{-1}$ ), at $0.3 \mathrm{~m}$ spacing $\left(16\right.$ emitters per bed $-n_{\mathrm{e}}$ ).

Equation 4 was used to estimate the gross irrigation depth (LB). A system application efficiency value $\left(E_{\mathrm{a}}\right)$ of $95 \%$ was adopted according to Pizarro Cabello's (1996) recommendations. The irrigation time $(T)$ was estimated by Eq. 5 .

$$
\mathrm{LB}=\frac{\mathrm{LL}}{E_{\mathrm{a}} \mathrm{UD}}
$$

where LB is the gross irrigation depth (mm), $E_{\mathrm{a}}$ is the application efficiency (decimal), and UD is the irrigation system uniformity of distribution (decimal).

$$
T=\mathrm{LB} \cdot \frac{A}{n_{\mathrm{e}} q_{\mathrm{a}}} \cdot 60
$$

where $T$ is the irrigation time ( $\mathrm{min}), A$ is the bed area $\left(\mathrm{m}^{2}\right) ; q_{\mathrm{a}}$ is the average flow of the emitters $\left(\mathrm{L} \cdot \mathrm{h}^{-1}\right)$, and $n_{\mathrm{e}}$ is the number of emitters per bed. 


\section{Evaluated parameters}

\section{Crop development}

During the experiment 3 plants of each treatment replicate were photographed weekly, until the $49^{\text {th }}$ day after transplanting. Figure 2 shows the scheme used to photograph the plants, as well as an example picture taken during the experiment.

Using the ImageJ software (1.52a version), the average exposed area of the photographed plants (Ap) was estimated over time for each treatment. The ruler readings were used to validate the information processed in the software. The time when the maximum exposed area (Apmax) occurred was determined.

After harvesting (57 days after transplanting) the stem length and diameter $\left(L_{\mathrm{s}}\right.$ and $\left.D_{\mathrm{s}}\right)$ of the plants were measured with a digital pachymeter (accuracy of $0.01 \mathrm{~mm}$ ).

The percentage of leaves with tip-burn (PFtb) was also assessed (Eq. 6). Tip-burn is characterized as a physiological disorder due to calcium deficiency, burning the edges of young leaf growth points, favouring the entry of microorganisms (Yuri et al., 2006; Turini et al., 2011).

$$
\mathrm{PLtb}=\frac{\mathrm{NLtb}}{\mathrm{NLt}} \times 100
$$

where PLtb is the percentage of leaves with tip-burn (\%), NLtb is the number of plant leaves with tip-burn, and NLt is the total number of plants leaves.

\section{Crop productive parameters}

The productive parameters evaluated were: total fresh and dry weight of the plants aerial shoot $\left(\mathrm{FW}_{\mathrm{t}}\right.$ and $\left.\mathrm{DW}_{\mathrm{t}}\right)$; commercial head fresh and dry weight $\left(\mathrm{FW}_{\mathrm{c}}\right.$ and $\left.\mathrm{DW}_{\mathrm{c}}\right)$; fresh and dry root weight $\left(\mathrm{FW}_{\mathrm{r}}\right.$ and $\left.\mathrm{DW}_{\mathrm{r}}\right)$; fresh and dry stem weight $\left(\mathrm{FW}_{\mathrm{s}}\right.$ and $\left.\mathrm{DW}_{\mathrm{s}}\right)$; total and commercial yield $\left(Y_{\mathrm{t}}\right.$ and $\left.Y_{\mathrm{c}}\right)$; water use efficiency related to total and commercial yield ( $\mathrm{WUE}_{\mathrm{t}}$ and $\mathrm{WUE}_{\mathrm{c}}$ ); and dry matter content $(C)$.

Fresh weights were measured immediately after harvest with a digital scale (0.01 g accuracy). Following the guidelines of Yuri et al. (2004), the commercial fresh weight $\left(\mathrm{FW}_{\mathrm{c}}\right)$ was determined after the removal of the darker external leaves that were in contact with the soil, leaving the lighter and more compact leaves. The dry weights were measured after drying the constituents in a forced circulation oven at $65^{\circ} \mathrm{C}$.

The total and commercial yield $\left(Y_{\mathrm{t}}\right.$ and $Y_{\mathrm{c}}$, respectively) were estimated using Eqs 7 and 8:

$$
Y_{t}=0.01 \frac{n_{\mathrm{p}} F W_{t}}{A}
$$

where $Y_{\mathrm{t}}$ is the total yield $\left(\mathrm{t} \cdot \mathrm{ha}^{-1}\right), n_{\mathrm{p}}$ is the number of plants in a bed, $\mathrm{FW}_{\mathrm{t}}$ is the total fresh weight of the plant aerial parts, and $A$ is the bed area $\left(\mathrm{m}^{2}\right)$.

$$
Y_{c}=0.01 \frac{n_{\mathrm{p}} F W_{c}}{A}
$$

where $Y_{\mathrm{c}}$ is the commercial yield $\left(\mathrm{t} \cdot \mathrm{ha}^{-1}\right), \mathrm{FW}_{\mathrm{c}}$ is the commercial head fresh weight of the plants.

Water use efficiency related to total and commercial yield $\left(\mathrm{WUE}_{\mathrm{t}}\right.$ and $\mathrm{WUE}_{\mathrm{c}}$, respectively) were estimated using Eqs 9 and 10:

$$
\mathrm{WUE}_{t}=\frac{Y_{t}}{\Sigma \mathrm{LB}}
$$

where $\mathrm{WUE}_{\mathrm{t}}$ is the water use efficiency related to total yield $\left(\mathrm{t} \cdot \mathrm{ha}^{-1} \cdot \mathrm{mm}^{-1}\right), Y_{\mathrm{t}}$ is the total yield $\left(\mathrm{t} \cdot \mathrm{ha}^{-1}\right)$, and $\Sigma \mathrm{LB}$ is the gross irrigation depth applied to each treatment $(\mathrm{mm})$.

$$
\mathrm{WUE}_{c}=\frac{Y_{c}}{\sum \mathrm{LB}}
$$

where $\mathrm{WUE}_{\mathrm{c}}$ is the water use efficiency related to commercial yield $\left(\mathrm{t} \cdot \mathrm{ha}^{-1} \cdot \mathrm{mm}^{-1}\right), Y_{\mathrm{c}}$ is the commercial yield $\left(\mathrm{t} \cdot \mathrm{ha}^{-1}\right)$.

The dry matter content $(C)$ is the ratio between the total dry $\left(\mathrm{DW}_{\mathrm{t}}\right)$ and fresh $\left(\mathrm{FW}_{\mathrm{t}}\right)$ weight of the plants' aerial parts (Eq. 11). According to Di Gioia et al. (2017), this index quantifies the conversion percentage from fresh to dry matter.

$$
C=\frac{\mathrm{DW}_{t}}{\mathrm{FW}_{t}} 100
$$

where $C$ is the dry matter content $(\%), \mathrm{DW}_{\mathrm{t}}$ is the average total dry weight of the plants aerial shoot $\left(\mathrm{g} \cdot \mathrm{plant}^{-1}\right)$, and $\mathrm{FW}_{\mathrm{t}}$ is the average total fresh weight of the plants aerial part $\left(\mathrm{g} \cdot\right.$ plant $\left.^{-1}\right)$.

\section{Data analysis}

The data were subjected to analysis of variance by the F Test at $5 \%$ probability, and the factors that showed significant differences were analysed using the Tukey test, also at $5 \%$ of probability, using the software SISVAR 5.7 (Ferreira, 2011).

\section{RESULTS AND DISCUSSION}

\section{Experimental weather conditions}

The air temperature recorded inside the greenhouse during the experiment were as follows: maximum temperature of 31.0 $\pm 2.4^{\circ} \mathrm{C}$, minimum temperature of $19.0 \pm 1.8^{\circ} \mathrm{C}$, and average temperature of $25.0 \pm 1.5^{\circ} \mathrm{C}$. For air relative humidity, maximum value was $91.2 \pm 6.3 \%$, minimum $41.0 \pm 9.2 \%$, and average 66.1 $\pm 5.9 \%$. For daily evaporated depth in the mini-evaporimeter, the maximum, minimum and average values were 8.91, 0.42 and $3.58 \mathrm{~mm} \cdot \mathrm{d}^{-1}$, respectively.

Figure 3 shows the temporal variability of the average, maximum and minimum air temperature, and relative humidity during the experiment, as well as the daily values of the evaporated water depth in the mini-evaporimeter.

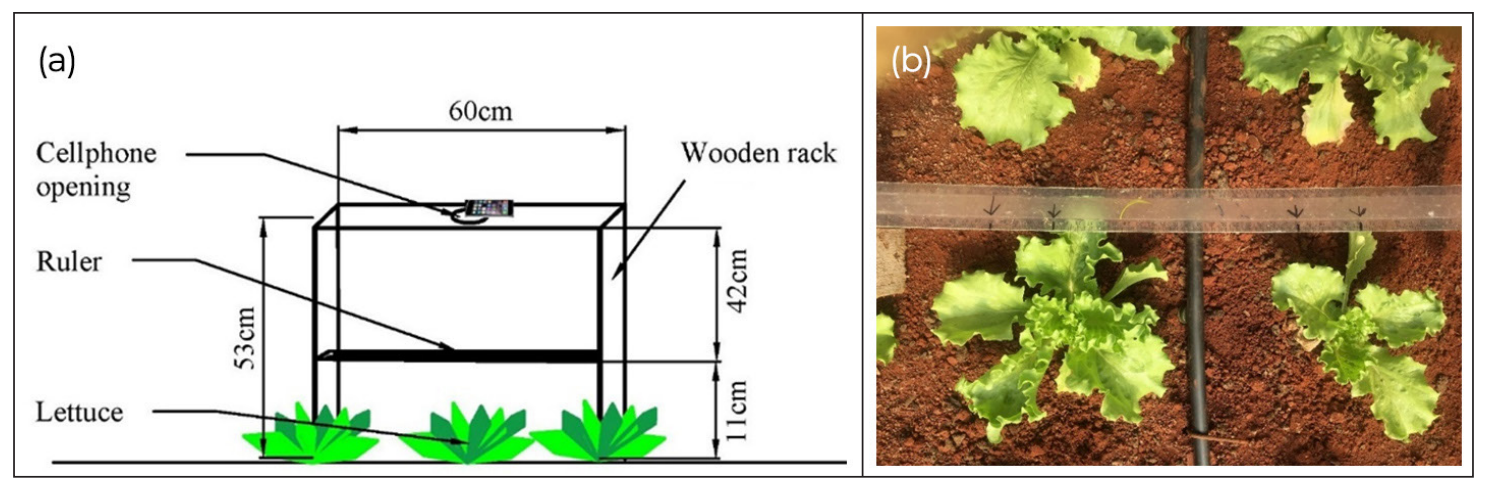

Figure 2. (a) Scheme of the structure used to take photographs of the plants in the experiment., (b) Example of a photo taken with details of the graduated ruler and the plants (b). 


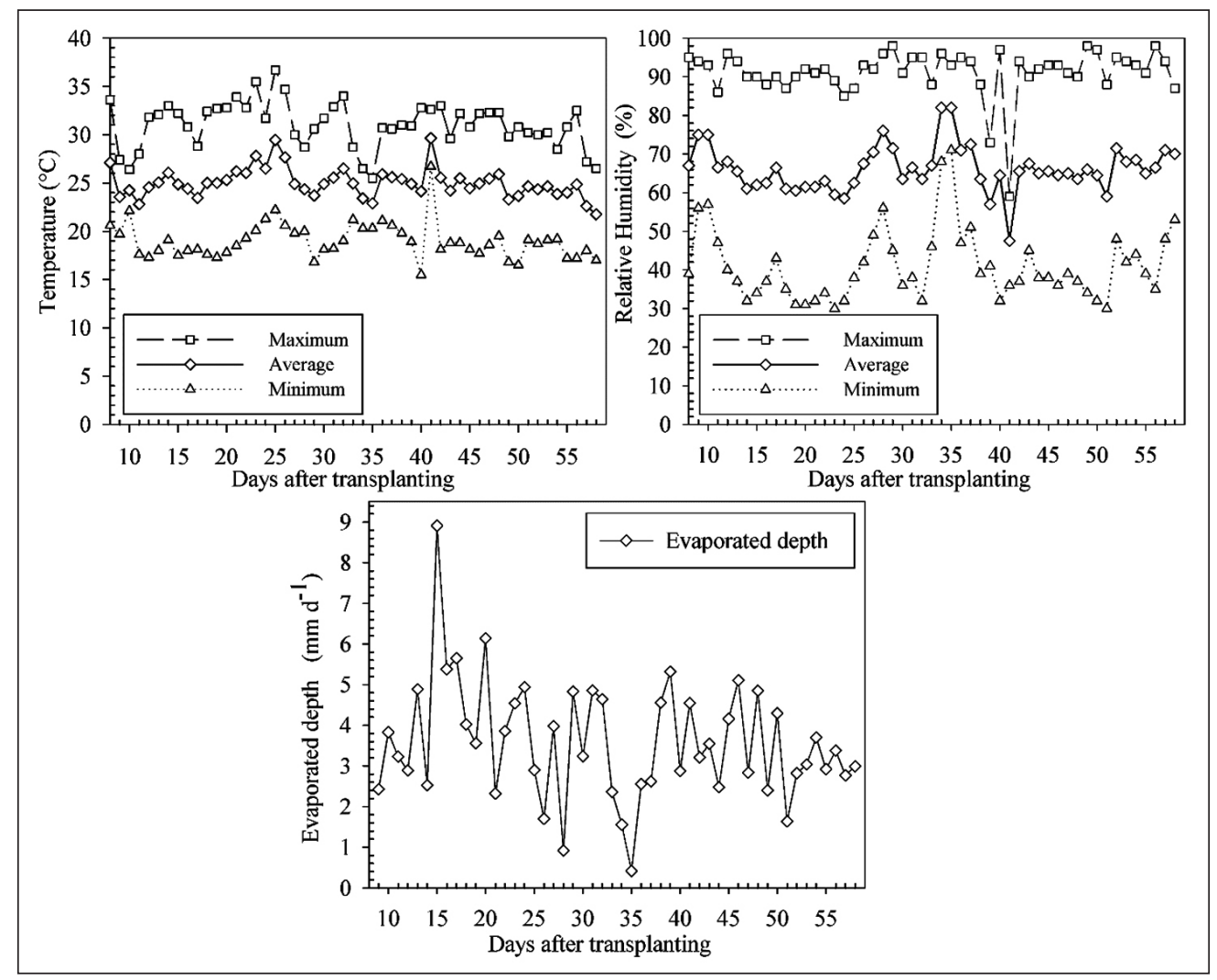

Figure 3. Maximum, average, and minimum temporal variability of air temperature, relative humidity, and evaporated water depth in the mini-evaporimeter, as a function of days after transplanting

According to FAO Plant Production and Protection Paper No. 230 (Baudoin et al., 2017), lettuce crop performance is greatly influenced by weather conditions, with better development occurring in the air temperature range of 7 to $23^{\circ} \mathrm{C}$, and relative humidity range 75 to $85 \%$. Despite these guidelines, Valeriano et al. (2016) obtained satisfactory development in lettuce subjected to an average temperature of $32.5^{\circ} \mathrm{C}$ and an average relative humidity of $62 \%$.

\section{Crop development}

Figure 4 presents average exposed area (Ap) of the lettuce plant as a function of the days after transplanting for the different experimental combinations.

Application of magnetically treated water resulted in a lower value of maximum exposed area (Apmax) - approximately $528 \mathrm{~cm}^{2}$ for magnetically treated water, and $658 \mathrm{~cm}^{2}$ for ordinary water. Additionally, it was observed that the timing of Apmax occurred around 42 days after transplanting for both types of water. Conversely, Putti et al. (2015a) observed a shorter development time for iceberg lettuce using magnetically treated water compared to ordinary water. Additionally, Adeniran et al. (2020) observed an increase in leaf area and height of Lagos spinach plants when using water subjected to magnetic treatment.

According to some authors, the magnetic treatment process results in water becoming more cohesive, with water clusters having smaller dimensions, causing greater attraction to soil particles and less movement of water in soil pores (Al-Ogaidi et al., 2017; Mostafazadeh-Fard et al., 2011; Surendran et al., 2016). The authors explain that the increase in cohesion is the result of the molecules being released from reaction with ions via hydrogen bonds and van der Waals forces, leading to greater ease of water penetration into soil micropores, reducing percolation. Additionally, the authors explain that calcium carbonate ions in the water form aragonite crystals after magnetic treatment, which are deposited in the soil. This elevates the soil osmotic potential, decreasing crop evapotranspiration and maintaining soil moisture content for a longer period. Surendran et al. (2016) pointed out that the maintenance of soil moisture for a longer time may also be associated with reduced evaporative capacity. Kareem and Adeniran (2020) also observed a reduction in Lagos spinach (Celosia argentea) evapotranspiration with the use of magnetically treated water.

As presented, the magnetic treatment of water resulted in lower soil water tension, maintaining soil moisture for a longer time, which would facilitate water and nutrient uptake by crops. However, based on the lower values recorded for average plant exposed area with magnetically treated water, it is hypothesized that, although soil moisture is retained for longer, the increase in water retention by the soil may have decreased water evaporation from the soil and, additionally, increased resistance for uptake of water by plant roots.

Regarding lettuce stem length $\left(L_{\mathrm{s}}\right)$ and diameter $\left(D_{\mathrm{s}}\right)$ for the different experimental combinations, there were no significant differences $(p \leq 0.05)$ for any of the factors evaluated. Average lettuce stem length and diameter were 93.3 and $16.1 \mathrm{~mm}$, respectively.

Maboko et al. (2007) recorded higher values for Lucy Brown lettuce in hydroponic cultivation, being 122.8 and $28.4 \mathrm{~mm}$ in length and stem diameter, respectively. According to Yuri et al. (2002), 'iceberg' lettuce stem length is important in the processing of the product, where values below $60 \mathrm{~mm}$ are the most appropriate, being acceptable up to $90 \mathrm{~mm}$. According to Neves et al. (2016), smaller stems decrease losses in processing, determine greater compactness to the heads of lettuce, and have greater bolting resistance (number of days between sowing and initial stem elongation, with the formation of floral structures). The average values achieved here $\left(L_{\mathrm{s}}=93.3 \mathrm{~mm}\right.$ and $\left.D_{\mathrm{s}}=16.1 \mathrm{~mm}\right)$ are thus not within the recommended limits. 


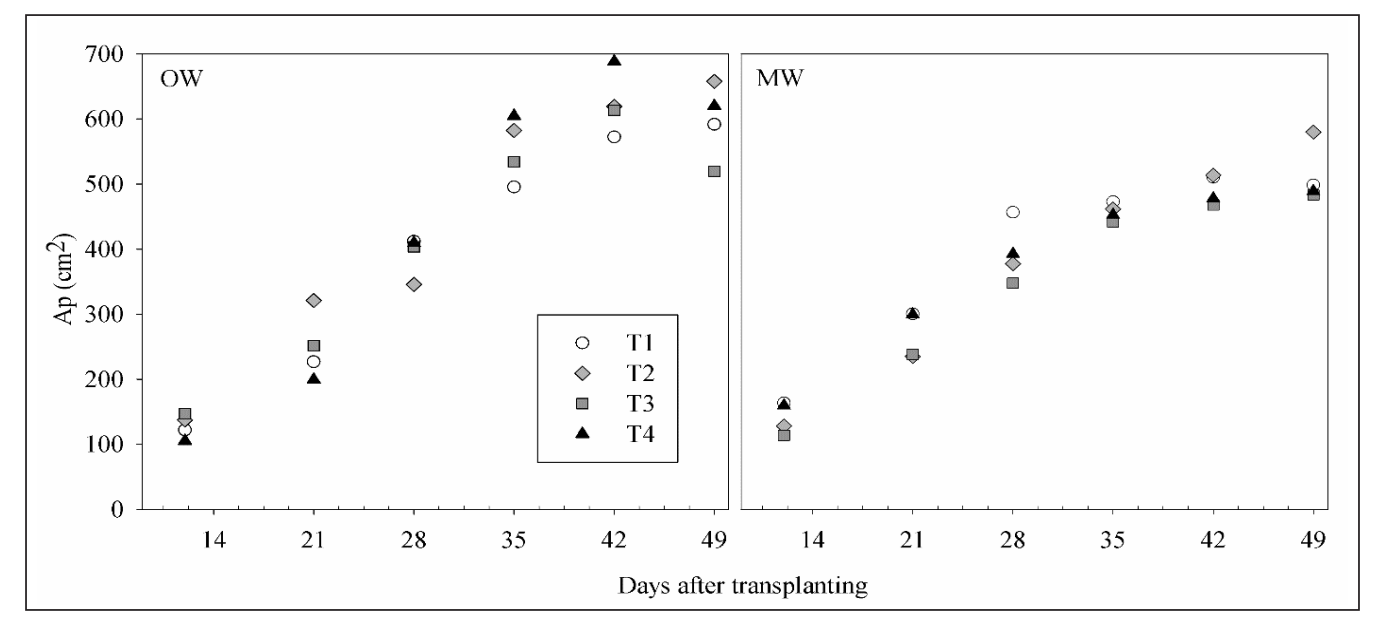

Figure 4. Average exposed area of the lettuce plant $\left(\mathrm{cm}^{2}\right)$ as a function of days after transplanting, for the different combinations of soil water tension at initiation of irrigation (T1, T2, T3 and T4) and water type (OW and MW)

A possible cause of the longer stem length achieved in the experiment may be the air temperature (Al-Said et al., 2018; Neves et al., 2016; Baudoin et al., 2017). These authors recommend an ideal air temperature range of 7 to $23^{\circ} \mathrm{C}$ for lettuce, whereas the present experiment recorded an average value of $25^{\circ} \mathrm{C}$ and occurrences of even higher temperatures (Fig. 3).

Table 2 shows the results of the Tukey test $(p \leq 0.05)$ conducted for the percentage of leaves with tip-burn (PLtb) vs the different experimental combinations.

Significant differences $(p \leq 0.05)$ were observed in PLtb only for type of water in the soil moisture condition closest to the field capacity (T1 treatment), with an increase of $75.62 \%$ with use of magnetically treated water. As the use of magnetically treated water was able to maintain soil moisture for a longer time (Fig. 4), this may have increased the occurrence of lettuce tip-burn. Plamondon et al. (2011) demonstrated a significant influence of soil water tension at initiation of irrigation with ordinary water on PLtb, where higher soil moisture determined higher values of PLtb.

\section{Crop production parameters}

Table 3 shows the results of a Tukey test $(p \leq 0.05)$ on total and commercial fresh weight $\left(\mathrm{FW}_{\mathrm{t}}\right.$ and $\left.\mathrm{FW}_{\mathrm{c}}\right)$, total and commercial dry weight $\left(\mathrm{DW}_{\mathrm{t}}\right.$ and $\left.\mathrm{DW}_{\mathrm{c}}\right)$, fresh and dry root weight $\left(\mathrm{FW}_{\mathrm{r}}\right.$ and $\left.\mathrm{DW}_{\mathrm{r}}\right)$, and fresh and dry stem weight $\left(\mathrm{FW}_{\mathrm{s}}\right.$ and $\left.\mathrm{DW}_{\mathrm{s}}\right)$.

None of the parameters showed significant differences due to the type of water used. The opposite was observed by Putti et al. (2015b), who recorded a significant increase in the fresh weight of iceberg lettuce using water subjected to magnetic treatment. Pradela et al. (2018) observed an increase in the dry weight of lettuce seedling aerial shoots using magnetically treated water. Most authors who have observed a significant effect using magnetically treated water in irrigation, impute this to the water's physical and chemical changes, resulting in improvements in the plant's ability to absorb water and nutrients, in addition to increasing the plant's rate of metabolic activities (Maheshwari and Grewal, 2009; Putti et al., 2015b; Ul Haq et al., 2016; Pradela et al., 2018).

With ordinary water use, it was observed that there were no significant differences $(p \leq 0.05)$ for any dependent variable due to the soil water tension at initiation of irrigation. The average values of the parameters were: $\mathrm{FW}_{\mathrm{t}}=516.75 \mathrm{~g} \cdot$ plant $^{-1}, \mathrm{FW}_{\mathrm{c}}=$ 447.21 g.plant ${ }^{-1}, \mathrm{DW}_{\mathrm{t}}=15.00 \mathrm{~g} \cdot$ plant $^{-1}, \mathrm{DW}_{\mathrm{c}}=10.89 \mathrm{~g} \cdot$ plant $^{-1}, \mathrm{FW}_{\mathrm{r}}$ $=7.38 \mathrm{~g} \cdot$ plant $^{-1}, \mathrm{DW}_{\mathrm{r}}=0.565 \mathrm{~g} \cdot$ plant $^{-1}, \mathrm{FW}_{\mathrm{s}}=32.13 \mathrm{~g} \mathrm{plant}^{-1}$, and $\mathrm{DW}_{\mathrm{s}}=1.26 \mathrm{~g} \mathrm{plant}^{-1}$. The average values of $\mathrm{FW}_{\mathrm{t}}, \mathrm{FW}_{\mathrm{c}}$ and $\mathrm{DW}$ were close to the values obtained by De Souza et al. (2013), being
574.8 g.plant ${ }^{-1}, 412.3$ g.plant ${ }^{-1}$ and 14.1 g.plant ${ }^{-1}$, respectively. Some authors have observed decreases in $\mathrm{FW}_{\mathrm{c}}$ values with increasing soil water tension at the initiation of irrigation (Santos and Pereira, 2004; Coelho et al., 2005). In the results presented by Silva et al. (2018) there was no significant difference in $\mathrm{FW}_{\mathrm{t}}$ by irrigation depth, however there was an increase in $\mathrm{DW}_{\mathrm{t}}$ and a reduction in $\mathrm{DW}_{\mathrm{r}}$ with irrigation depth increase. The same trend was found by Putti et al. (2015b) for $\mathrm{DW}_{\mathrm{r}}$.

For the use of magnetically treated water, a significant reduction $(p \leq 0.05)$ of the parameters FWt, $\mathrm{FW}_{\mathrm{c}}, \mathrm{DW}_{\mathrm{t}}, \mathrm{FW}_{\mathrm{r}}, \mathrm{FW}_{\mathrm{s}}$ and $\mathrm{DW}_{\mathrm{s}}$ was observed with an increase soil water tension at initiation of irrigation, being: $\mathrm{T} 1>\mathrm{T} 2=\mathrm{T} 3>\mathrm{T} 4$ for $\mathrm{FW}_{\mathrm{t}}, \mathrm{T} 1=\mathrm{T} 2=\mathrm{T} 3>\mathrm{T} 4$ for $\mathrm{FW}_{\mathrm{c}}, \mathrm{T} 1=\mathrm{T} 2>\mathrm{T} 3=\mathrm{T} 4$ for $\mathrm{DW}_{\mathrm{t}}, \mathrm{T} 1>\mathrm{T} 2=\mathrm{T} 3=\mathrm{T} 4$ for $\mathrm{FW}_{\mathrm{r}}$, $\mathrm{T} 1=\mathrm{T} 2=\mathrm{T} 3>\mathrm{T} 4$ for FWs, and $\mathrm{T} 1>\mathrm{T} 2=\mathrm{T} 3=\mathrm{T} 4$ for $\mathrm{DW}_{\mathrm{s}}$. Analogous to these results, Putti et al. (2015b) obtained an increase in iceberg lettuce $\mathrm{FW}_{\mathrm{t}}, \mathrm{DW}_{\mathrm{t}}$ and $\mathrm{FW}_{\mathrm{r}}$ with increase in magnetically treated water depth. Zlotopolski (2017) also obtained benefits from an increase in depth increase, resulting in an increase in lettuce $\mathrm{FW}_{\mathrm{t}}$.

The parameters of $\mathrm{DW}_{\mathrm{c}}$ and $\mathrm{DW}_{\mathrm{r}}$ did not show a significant influence ( $p \leq 0.05$ ) of modifying soil water tension at initiation of irrigation using magnetically treated water. Average values for $\mathrm{DW}_{\mathrm{c}}$ and $\mathrm{DW}_{\mathrm{r}}$ were 11.67 and $0.633 \mathrm{~g} \cdot$ plant $^{-1}$, respectively.

Considering the hypothesis that irrigation with magnetically treated water resulted in an increase in the resistance to water uptake by the plants, the increase in soil water tension at the initiation of irrigation intensified this resistance, resulting in a decrease in most of the production parameters. This contradicts what has been reported observed by some authors, who recorded better performance in the productive parameters of several crops using magnetically treated water. An increase in total and commercial fresh weight, as well as fresh root weight, and amount of nutrients absorbed by plants was observed with magnetically treated water, even for the lowest water depths (Putti et al., 2015b; Yusuf and Ogunlela, 2017; Zlotopolski, 2017; Selim et al., 2019; Adeniran et al., 2020).

Table 4 shows the results for Tukey tests $(p \leq 0.05)$ on total and commercial yield ( $Y_{\mathrm{t}}$ and $Y_{c}$, respectively), water use efficiency referring to total and commercial yield $\left(\mathrm{WUE}_{\mathrm{t}}\right.$ and $\mathrm{WUE}_{\mathrm{c}}$ ), and dry matter content $(C)$, for different experimental combinations.

The type of water significantly influenced $(p \leq 0.05)$ the $\mathrm{WUE}_{\mathrm{t}}$ (average of $0.69 \mathrm{t} \cdot \mathrm{ha}^{-1} \cdot \mathrm{mm}^{-1}$ for MW, and $0.48 \mathrm{t} \cdot \mathrm{ha}^{-1} \cdot \mathrm{mm}^{-1}$ for OW) and $\mathrm{WUE}_{\mathrm{c}}$ (average of $0.62 \mathrm{t} \cdot \mathrm{ha}^{-1} \cdot \mathrm{mm}^{-1}$ for $\mathrm{MW}$, and $0.42 \mathrm{t} \cdot \mathrm{ha}^{-1} \cdot \mathrm{mm}^{-1}$ for $\mathrm{OW}$ ), when using tension $\mathrm{T} 1$ for irrigation management. An increase of 43.8 and $47.6 \%$ for $\mathrm{WUE}_{\mathrm{t}}$ and $\mathrm{WUE}_{\mathrm{c}}$, respectively, was 
observed using magnetically treated water compared to ordinary water. Conversely, Putti et al. (2015b) found an increase in lettuce yield and dry weight using magnetically treated water.

In the use of magnetically treated water, a significant reduction $(p \leq 0.05)$ of $Y_{\mathrm{t}}, Y_{\mathrm{c}}, \mathrm{WUE}_{\mathrm{t}}$, and $\mathrm{WUE}_{\mathrm{c}}$ was observed with increasing soil water tension at initiation of irrigation: $\mathrm{T} 1>\mathrm{T} 2=\mathrm{T} 3>\mathrm{T} 4$ for $Y_{\mathrm{t}}, \mathrm{T} 1=\mathrm{T} 2=\mathrm{T} 3>\mathrm{T} 4$ for $Y_{\mathrm{c}}, \mathrm{T} 1>\mathrm{T} 2=\mathrm{T} 3=\mathrm{T} 4$ for $\mathrm{WUE}_{\mathrm{t}}$, and $\mathrm{T} 1>\mathrm{T} 2=\mathrm{T} 3=\mathrm{T} 4$ for $\mathrm{WUE}_{c}$. For parameter $\mathrm{C}$, an increase was observed with increasing soil water tension at initiation of irrigation $(\mathrm{T} 4>\mathrm{T} 2>\mathrm{T} 1=\mathrm{T} 3)$.

Table 2. Percentage of lettuce leaves with tip-burn (\%), for different combinations between soil water tensions at initiation of irrigation (T1, T2, T3 and T4) and water type (OW and MW) ${ }^{1}$

\begin{tabular}{lccc}
\hline Type of water & \multicolumn{3}{c}{ Soil water tension at initiation of irrigation } \\
\cline { 2 - 4 } & T1 & T2 & T3 \\
\hline Ordinary water & $16.01 \mathrm{bA}$ & $17.00 \mathrm{aA}$ & $17.41 \mathrm{aA}$ \\
Magnetically treated water & $28.09 \mathrm{aA}$ & $14.72 \mathrm{aA}$ & $14.84 \mathrm{aA}$ \\
\hline
\end{tabular}

${ }^{1}$ Different lowercase letters in the vertical differ significantly $(\mathrm{p} \leq 0.05)$ with changing water type, and different uppercase letters in the horizontal differ significantly $(\mathrm{p} \leq 0.05)$ with changing soil water tension at initiation of irrigation (Tukey test)

Table 3. 'Iceberg' lettuce total and commercial fresh weight ( $F W_{t}$ and $\left.F W_{c}\right)$, total and commercial dry weight (DWt and DWc), fresh and dry root weight $\left(\mathrm{FW}_{\mathrm{r}}\right.$ and $\left.\mathrm{DW}_{\mathrm{r}}\right)$, and fresh and dry stem weight $\left(\mathrm{FW}_{\mathrm{s}}\right.$ and $\left.\mathrm{DW}_{\mathrm{s}}\right)$, for the different experimental combinations ${ }^{1}$

\begin{tabular}{|c|c|c|c|c|c|}
\hline \multirow[t]{2}{*}{ Parameter } & \multirow[t]{2}{*}{ Type of water } & \multicolumn{4}{|c|}{ Soil water tension to start irrigation } \\
\hline & & $\mathrm{T} 1$ & T2 & T3 & T4 \\
\hline \multirow{2}{*}{$\begin{array}{l}\mathrm{FW}_{\mathrm{t}} \\
\left(\mathrm{g} \cdot \text { plant }^{-1}\right)\end{array}$} & Ordinary water & $604.77 \mathrm{aA}$ & $513.45 \mathrm{aA}$ & $544.29 \mathrm{aA}$ & $404.50 \mathrm{aA}$ \\
\hline & Magnetically treated water & $563.42 \mathrm{aA}$ & $493.23 \mathrm{aB}$ & $490.38 \mathrm{aB}$ & $315.17 \mathrm{aC}$ \\
\hline \multirow{2}{*}{$\begin{array}{l}\mathrm{FW}_{\mathrm{c}} \\
\left(\mathrm{g} \cdot \text { plant }^{-1}\right)\end{array}$} & Ordinary water & 529.85 aA & 414.78 aA & $480.29 \mathrm{aA}$ & $363.90 \mathrm{aA}$ \\
\hline & Magnetically treated water & $505.63 \mathrm{aA}$ & $439.12 \mathrm{aA}$ & 435.46 aA & $252.53 \mathrm{aB}$ \\
\hline \multirow{2}{*}{$\begin{array}{l}\mathrm{DW}_{\mathrm{t}} \\
\left(\mathrm{g} \cdot \text { plant }^{-1}\right)\end{array}$} & Ordinary water & $15.22 \mathrm{aA}$ & $13.92 \mathrm{aA}$ & $15.92 \mathrm{aA}$ & $14.93 \mathrm{aA}$ \\
\hline & Magnetically treated water & $16.50 \mathrm{aA}$ & $16.57 \mathrm{aA}$ & $14.00 \mathrm{aB}$ & $13.19 \mathrm{aB}$ \\
\hline \multirow{2}{*}{$\begin{array}{l}\mathrm{DW}_{c} \\
\left(\mathrm{~g} \cdot \text { plant }^{-1}\right)\end{array}$} & Ordinary water & $11.23 \mathrm{aA}$ & $10.45 \mathrm{aA}$ & $10.67 \mathrm{aA}$ & $11.40 \mathrm{aA}$ \\
\hline & Magnetically treated water & $13.37 \mathrm{aA}$ & $12.39 \mathrm{aA}$ & $10.98 \mathrm{aA}$ & $9.94 \mathrm{aA}$ \\
\hline \multirow{2}{*}{$\begin{array}{l}\mathrm{FW}_{\mathrm{r}} \\
\left(\mathrm{g} \cdot \text { plant }^{-1}\right)\end{array}$} & Ordinary water & 7.99 aA & $7.34 \mathrm{aA}$ & $7.05 \mathrm{aA}$ & $7.13 \mathrm{aA}$ \\
\hline & Magnetically treated water & $9.68 \mathrm{aA}$ & $7.63 \mathrm{aB}$ & $7.60 \mathrm{aB}$ & $6.91 \mathrm{aB}$ \\
\hline \multirow{2}{*}{$\begin{array}{l}\mathrm{DW}_{\mathrm{r}} \\
\left(\mathrm{g} \cdot \text { plant }^{-1}\right)\end{array}$} & Ordinary water & $0.62 \mathrm{aA}$ & $0.54 \mathrm{aA}$ & $0.51 \mathrm{aA}$ & $0.59 \mathrm{aA}$ \\
\hline & Magnetically treated water & $0.91 \mathrm{aA}$ & $0.55 \mathrm{aA}$ & $0.58 \mathrm{aA}$ & $0.59 \mathrm{aA}$ \\
\hline \multirow{2}{*}{$\begin{array}{l}\mathrm{FW}_{\mathrm{s}} \\
\text { (g.plant }{ }^{-1} \text { ) }\end{array}$} & Ordinary water & $45.14 \mathrm{aA}$ & $25.97 \mathrm{aA}$ & $35.02 \mathrm{aA}$ & $22.37 \mathrm{aA}$ \\
\hline & Magnetically treated water & $32.41 \mathrm{aA}$ & $30.67 \mathrm{aA}$ & $30.39 \mathrm{aA}$ & $13.05 \mathrm{aB}$ \\
\hline \multirow{2}{*}{$\begin{array}{l}\mathrm{DW}_{\mathrm{s}} \\
\left(\mathrm{g} \cdot \text { plant }^{-1}\right)\end{array}$} & Ordinary water & $1.63 \mathrm{aA}$ & $1.16 \mathrm{aA}$ & $1.25 \mathrm{aA}$ & $0.99 \mathrm{aA}$ \\
\hline & Magnetically treated water & $1.45 \mathrm{aA}$ & $1.14 \mathrm{aB}$ & $1.16 \mathrm{aB}$ & $0.7 \mathrm{aB}$ \\
\hline
\end{tabular}

${ }^{1}$ Different lowercase letters in the vertical differ significantly ( $\left.\mathrm{p} \leq 0.05\right)$ with changing water type for the same parameter, and different uppercase letters in the horizontal differ significantly $(\mathrm{p} \leq 0.05)$ with changing soil water tension at initiation of irrigation (Tukey test)

Table 4. Total and commercial yield $\left(\mathrm{Y}_{\mathrm{t}}\right.$ and $\left.\mathrm{Y}_{\mathrm{c}}\right)$, water use efficiency referring to total and commercial yield $\left(\mathrm{WUE}_{\mathrm{t}}\right.$ and WUE $\mathrm{E}_{\mathrm{c}}$, and dry matter content $(C)$ of lettuce for the different experimental combinations ${ }^{1}$

\begin{tabular}{|c|c|c|c|c|c|}
\hline \multirow[t]{2}{*}{ Parameter } & \multirow[t]{2}{*}{ Type of water } & \multicolumn{4}{|c|}{ Soil water tension at initiation of irrigation } \\
\hline & & T1 & T2 & T3 & T4 \\
\hline \multirow[t]{2}{*}{$Y_{t}\left(t \cdot h a^{-1}\right)$} & Ordinary water & $67.19 \mathrm{aA}$ & $57.05 \mathrm{aA}$ & $60.48 \mathrm{aA}$ & $44.94 \mathrm{aA}$ \\
\hline & Magnetically treated water & $62.60 \mathrm{aA}$ & $54.80 \mathrm{aB}$ & $54.49 \mathrm{aB}$ & $35.02 \mathrm{aC}$ \\
\hline \multirow[t]{2}{*}{$Y_{c}\left(t \cdot h a^{-1}\right)$} & Ordinary water & $58.87 \mathrm{aA}$ & $46.09 \mathrm{aA}$ & $53.37 \mathrm{aA}$ & $40.43 \mathrm{aA}$ \\
\hline & Magnetically treated water & $56.17 \mathrm{aA}$ & $48.79 \mathrm{aA}$ & $48.38 \mathrm{aA}$ & $28.06 \mathrm{aB}$ \\
\hline \multirow[t]{2}{*}{ WUE $_{\mathrm{t}}\left(\mathrm{t} \cdot \mathrm{ha}^{-1} \cdot \mathrm{mm}^{-1}\right)$} & Ordinary water & $0.48 \mathrm{bA}$ & $0.43 \mathrm{aA}$ & $0.36 \mathrm{aA}$ & $0.46 \mathrm{aA}$ \\
\hline & Magnetically treated water & $0.69 \mathrm{aA}$ & $0.38 \mathrm{aB}$ & $0.39 \mathrm{aB}$ & $0.49 \mathrm{aB}$ \\
\hline \multirow[t]{2}{*}{ WUE $_{c}\left(\mathrm{t} \cdot h \mathrm{a}^{-1} \cdot \mathrm{mm}^{-1}\right)$} & Ordinary water & $0.42 \mathrm{bA}$ & $0.35 \mathrm{aA}$ & $0.31 \mathrm{aA}$ & $0.41 \mathrm{aA}$ \\
\hline & Magnetically treated water & $0.62 \mathrm{aA}$ & $0.33 \mathrm{aB}$ & $0.35 \mathrm{aB}$ & $0.39 \mathrm{aB}$ \\
\hline \multirow[t]{2}{*}{ C (\%) } & Ordinary water & $2.54 \mathrm{aC}$ & $2.77 \mathrm{aB}$ & $3.04 \mathrm{aB}$ & $3.75 \mathrm{aA}$ \\
\hline & Magnetically treated water & $2.95 \mathrm{aC}$ & $3.39 \mathrm{aB}$ & $2.86 \mathrm{aC}$ & $4.19 \mathrm{aA}$ \\
\hline
\end{tabular}

${ }^{1}$ Different lowercase letters in the vertical differ significantly $(\mathrm{p} \leq 0.05)$ with changing water type for the same parameter, and different uppercase letters in the horizontal differ significantly $(\mathrm{p} \leq 0.05)$ with changing soil water tension at initiation of irrigation (Tukey Test) 
With the use of ordinary water, changing the soil water tension at initiation of irrigation only had a significant effect on $C$ $(p \leq 0.05)$; increasing soil water tension resulted in an increase in $C(\mathrm{~T} 4>\mathrm{T} 3=\mathrm{T} 2>\mathrm{T} 1)$. This corroborates the finding of Dos Santos and Pereira (2004), who point out that reduced values of $C$ for lettuce crop are desirable, providing more flavour despite obtaining shorter post-harvest storage time/shelf-life.

The average values of $Y_{\mathrm{t}}, Y_{\mathrm{c}}, \mathrm{WUE}_{\mathrm{t}}$, and $\mathrm{WUE}_{\mathrm{c}}$ for the tensions using ordinary water were, respectively: $57.42 \mathrm{t} \cdot \mathrm{ha}^{-1}, 49.69 \mathrm{t} \cdot \mathrm{ha}^{-1}$, $0.42 \mathrm{t} \cdot \mathrm{ha}^{-1} \cdot \mathrm{mm}^{-1}$ and $0.37 \mathrm{t} \cdot \mathrm{ha}^{-1} \cdot \mathrm{mm}^{-1}$. Dos Santos and Pereira (2004) observed a reduction in $\mathrm{WUE}_{\mathrm{t}}$ values with increasing soil water tension at initiation of irrigation, ranging from $0.469 \mathrm{t} \cdot \mathrm{ha}^{-1} \cdot \mathrm{mm}^{-1}(-15$ $\mathrm{kPa})$ to $0.380 \mathrm{t} \cdot \mathrm{ha}^{-1} \cdot \mathrm{mm}^{-1}(-51.95 \mathrm{kPa})$. Maggi et al. (2006) recorded the highest value of $\mathrm{WUE}_{\mathrm{t}}\left(0.3685 \mathrm{t} \cdot \mathrm{ha}^{-1} \cdot \mathrm{mm}^{-1}\right)$ for lettuce in irrigation management using $-35 \mathrm{kPa}$ soil water tension to initiate irrigation. On the other hand, Kirnak et al. (2016) obtained an increase in lettuce yield by increasing irrigation depth. Coelho et al. (2005) observed an increase in Lucy Brown lettuce total and commercial yields with a reduction in soil water tension at initiation of irrigation. These authors observed the highest values of $Y_{\mathrm{t}}\left(69.85 \mathrm{t} \cdot \mathrm{ha}^{-1}\right)$ and $Y_{c}$ $\left(59.40 \mathrm{t}^{\mathrm{h}} \mathrm{ha}^{-1}\right)$ for the treatment closest to field capacity $(-27.92 \mathrm{kPa})$.

Neves et al. (2016) obtained an average total yield of $24.13 \mathrm{t} \cdot \mathrm{ha} \mathrm{a}^{-1}$ for lettuce Lucy Brown grown on open field and protected environment. According to the authors, this low value was attributed to the occurrence of high temperatures during the experiment.

Lima Junior et al. (2010) observed a quadratic relationship for total and commercial yield for Raider-Plus lettuce vs water depth; total and commercial productivity increased as irrigation depths increased. The maximum total yield was estimated with a water depth of $203.9 \mathrm{~mm}$, equivalent to $65.58 \mathrm{t} \cdot \mathrm{ha}^{-1}$, while for commercial lettuce head the maximum point was reached with an irrigation water application of $204.3 \mathrm{~mm}$, resulting in a $35.31 \mathrm{t} \cdot \mathrm{ha}^{-1}$ yield. For Laureau lettuce, Lima Junior et al. (2012) also found a relationship for total and commercial yield vs water depth that can be explained by a quadratic regression. The maximum point for total yield was estimated with a $159.1 \mathrm{~mm}$ irrigation water depth, equivalent to a yield of $66.9 \mathrm{t} \cdot \mathrm{ha}^{-1}$; and for commercial head, an irrigation depth of $164.8 \mathrm{~mm}$ resulted in a yield of $36.5 \mathrm{t} \cdot \mathrm{ha}^{-1}$.

The non-significant effect on total (average of $57.42 \mathrm{t} \cdot \mathrm{ha}^{-1}$ ) and commercial (average of $49.69 \mathrm{t} \cdot \mathrm{ha}^{-1}$ ) yield of lettuce from modifying soil water tension at initiation of irrigation with ordinary water may be explained by the possibility that the error of the soil water retention curve performed in the field (1.3\%) may have reduced the necessary differences between irrigation depths, and consequently reduced the possibility of significant differences in the evaluated parameters at the $5 \%$ level of probability.

\section{CONCLUSION}

Although the use of magnetically treated water increased the water use efficiency of lettuce production (only for the T1 soil water tension), damage to plants was evident as the lowest maximum exposure area and the highest percentage occurrence of tip-burn. In addition, irrigation with magnetically treated resulted in a reduction in crop production parameters with increasing soil water tension at initiation of irrigation, potentially due to a higher resistance to water uptake by the plants. In this context, despite the observed water savings, the use of this technology in crops where water availability is restricted cannot yet be considered, without deeper investigations of technical and economic feasibility, for different crop types and edaphoclimatic conditions.

\section{ACKNOWLEDGEMENTS}

This study was financed in part by the Coordenação de Aperfeiçoamento de Pessoal de Nível Superior - Brasil (CAPES) - Finance Code 001.

\section{ORCIDS}

Lis Tavares Ordones Lemos

https://orcid.org/0000-0002-2970-5448

Michael Silveira Thebaldi

https://orcid.org/0000-0002-4579-6714

\section{REFERENCES}

ADENIRAN KA, KAREEM KY, YUSUF KO and AFOLAYAN SO (2020) Effects of electromagnetic treatment of irrigation water on growth and yield of Lagos spinach (Celosia argentae). Agric. Eng. Int. 22 (2) 32-40.

AL-OGAIDI AAM, WAYAYOK A, ROWSHON MK and ABDULLAH AF (2017) The influence of magnetized water on soil water dynamics under drip irrigation systems. Agric. Water Manage. 180 70-77. https://doi.org/10.1016/j.agwat.2016.11.001

AL-SAID F, HADLEY P, PEARSON S, KHAN MM and IQBAL Q (2018) Effect of high temperature and exposure duration on stem elongation of iceberg lettuce. Pakistan J. Agric. Sci. 55 (1) 95-101. https://doi.org/10.21162/PAKJAS/18.6554

ALVARES CA, STAPE JL, SENTELHAS PC, GONÇALVES JLM and SPAROVEK G (2013) Köppen's climate classification map for Brazil. Meteorol. Z. 22 (6) 711-728. https://doi.org/10.1127/09412948/2013/0507

AZEVEDO J and SILVA E (1999) Tensiômetro: dispositivo prático para controle da irrigação. Embrapa Cerrados, Brasília, DF, Brazil. 37 pp.

BAUDOIN W, NERSISYAN A, SHAMILOV A, HODDER A, GUTIERREZ D, PASCALE S, NICOLA S, GRUDA N, URBAN L and TANNY J (2017) Good Agricultural Practices for Greenhouse Vegetable Production in the South East European Countries Principles for Sustainable Intensification of Smallholder Farms. FAO, Rome, 428 pp.

CAI R, YANG H, HE J and ZHU W (2009) The effects of magnetic fields on water molecular hydrogen bonds. J. Molec. Struct. 938 (1-3) 15-19. https://doi.org/10.1016/j.molstruc.2009.08.037

COELHO AFS, GOMES ÉP, SOUSA ADP and GLÓRIA MBA (2005) Effect of irrigation level on yield and bioactive amine content of American lettuce. J. Sci. Food Agric. 85 (6) 1026-1032. https://doi. org/10.1002/jsfa.2064

DI GIOIA F, GONNELLA M, BUONO V, AYALA O, CACCHIARELLI $\mathrm{J}$ and SANTAMARIA P (2017) Calcium cyanamide effects on nitrogen use efficiency, yield, nitrates, and dry matter content of lettuce. Agron. J. 109 (1) 354-362. https://doi.org/10.2134/agronj 2016.06.0366

FERREIRA DF (2011) Sisvar: a computer statistical analysis system. Ciên. Agrotecnol. 35 (6) 1039-1042. https://doi.org/10.1590/S141370542011000600001

GEISENHOFF LO, PEREIRA GM, LIMA JUNIOR JA DE, SILVA ALP and AVIZ WLC (2016) Greenhouse crisphead lettuce grown with mulching and under different soil water tensions. Eng. Agrícol. 36 (1) 46-54. https://doi.org/10.1590/1809-4430-Eng.Agric.v36n1p46$54 / 2016$

GREWAL HS and MAHESHWARI BL (2011) Magnetic treatment of irrigation water and snow pea and chickpea seeds enhances early growth and nutrient contents of seedlings. Bioelectromagnetics. 32 (1) 58-65. https://doi.org/10.1002/bem.20615

HOTTA LFK (2008) Interação de progênies de alface do grupo americano por épocas de cultivo. Master's thesis, Universidade Estatudal Paulista.

JABRO JD, EVANS RG and KIM Y (2009) Estimating in situ soil-water retention and field water capacity in two contrasting soil textures. Irrig. Sci. 27 223-229. https://doi.org/10.1007/s00271-008-0137-9

KAREEM KY and ADENIRAN KA (2020) Effects of electromagnetic irrigation water on Lagos Spinach evapotranspiration using lysimetric method. Agric. Eng. Int. 22 (2) 41-48.

KHOSHRAVESH-MIANGOLEH M and KIANI A-R (2014) Effect of magnetized water on infiltration capacity of different soil textures. Soil Use Manage. 30 (4) 588-594. https://doi.org/10.1111/sum.12140

KIRNAK H, TAŞ I, GÖKALP Z and KARAMAN S (2016) Effects of different irrigation levels on yield of lettuce grown in an unheated greenhouse. Curr. Trends Nat. Sci. 5 (9) 145-151. 
KIST BB, SANTOS CE DOS, DE CARVALHO C and BELING RR (2020) Anuário Brasileiro de Horti \& Fruti 2020. Editora Gazeta, Santa Cruz do Sul. 98 pp.

LEMOS LTO, DE DEUS FP, THEBALDI MS, DIOTTO AV, ANDRADE JÚNIOR VC and ALMEIDA RC (2021) Influence of the soil water retention curve type and magnetic water treatment on lettuce irrigation management responses. Water Supply 21 (6) 2850-2862. https://doi.org/10.2166/ws.2021.038

LIMA JUNIOR JA, PEREIRA GM, GEISENHOFF LO, VILAS BOAS RC and YURI JE (2010) Efeito da irrigação sobre o rendimento produtivo da alface americana, em cultivo protegido. Rev. Brasil. Eng. Agrícol. Ambien. 14 (8) 797-803.

LIMA JUNIOR JA, PEREIRA GM, GEISENHOFF LO, VILAS BOAS RC, SILVA WG and SILVA ALP (2012) Yield of crisphead lettuce under different amounts of irrigation. Semina: Ciên. Agrár. 33 (6) 2681-2688. https://doi.org/10.5433/1679-0359.2012v33Supllp2681

MABOKO MM, PLOOY CPDU and BROWN L (2007) Production of crisphead lettuce in a soilless production system. In: African Crop Science Conference Proceedings, 27-31 October 2007, El-Minia.

MAGGI MF, KLAR AE, JADOSKI CJ and ANDRADE ARS (2006) Lettuce production under different soil water potencial in protected enviromment. Irriga. 11 (3) 415-427. https://doi.org/10.15809/irriga. 2006v1ln3p415-427

MAHESHWARI BL and GREWAL HS (2009) Magnetic treatment of irrigation water: Its effects on vegetable crop yield and water productivity. Agric. Water Manage. 96 (8) 1229-1236. https://doi. org/10.1016/j.agwat.2009.03.016

MOSTAFAZADEH-FARD B, KHOSHRAVESH M, MOUSAVI SF and KIANI AR (2011) Effects of magnetized water and irrigation water salinity on soil moisture distribution in trickle irrigation. J. Irrig. Drain. Eng. 137 (6) 398-402. https://doi.org/10.1061/(ASCE) IR.1943-4774.0000304

MURAKAMI T, YAMADA K and YOSHIDA S (2002) Root distribution of field-grown crisphead lettuce (Lactuca sativa L.) under different fertilizer and mulch treatment. Soil Sci. Plant Nutr. 48 (3) 347-355. https://doi.org/10.1080/00380768.2002.10409211

NEVES JFNF, NODARI IDE, SEABRA JÚNIOR S, DIAS LDE, SILVA LBS and DALLACORT R (2016) Produção de cultivares de alface americana sob diferentes ambientes em condições tropicais.Rev.Agro@mbiente On-Line. 10 (2) 130-136. https://doi. org/10.18227/1982-8470ragro.v10i2.3200

PANG X, DENG B and TANG BO (2012) Influences of magnetic field on macroscopic properties of water. Mod. Phys. Lett. B. 26 (11) 1250069 1-1250069 13. https://doi.org/10.1142/S0217984912500698

PANG X and DENG B (2008) Investigation of changes in properties of water under the action of a magnetic field. Sci. China Ser. G: Phys. Mech. Astron. 51 1621-1632. https://doi.org/10.1007/s11433-008-0182-7

PIZARRO CABELLO F (1996) Riegos Localizados de Alta Frecuencia (RLAF): Goteo, Microaspersión, Exudación. Mundi-Prensa Libros, Madrid. 513 pp.

PLAMONDON L, GAUDREAU L, GOSSELIN A, CARON J, JENNI $S$ and VAN WINDEN D (2011) Effect of soil depth on water management of romaine lettuce (Lactuca sativa L.) cultivated in a muck soil. Acta Horticult. 889 453-458. https://doi.org/10.17660/ ActaHortic.2011.889.57

PRADELA VA, YOSHIDA CHP, SANTOS RC and LAPAZ AM (2018) Produção de mudas de alface em resposta ao uso de água tratada magneticamente. Rev. Brasil. Eng. Biossistem. 12 (3) 299-306

PUTTI FF, GABRIEL FILHO LRA, CREMASCO CP and KLAR AE (2015a) Fuzzy modeling of development of sheets number in different irrigation levels of irrigated lettuce with magnetically treated water. In: Proc. $7^{\text {th }}$ International Joint Conference on Computational Intelligence, 12-14 November 2015, Lisbon. https:// doi.org/10.5220/0005599701620169

PUTTI FF, GABRIEL FILHO LRA, KLAR AE, SILVA JUNIOR JF, CREMASCO CP and LUDWIG R (2015b) Response of lettuce crop to magnetically treated irrigation water and different irrigation depths. Afr. J. Agric. Res. 10 (22) 2300-2308. https://doi.org/10.5897/ AJAR2015.9616

RIBEIRO AC, GUIMARÃES PTG and ALVAREZ VVH (1999) Recomendação para o uso de corretivos e fertilizantes em Minas Gerais. Sociedade Brasileira de Ciência do Solo, Viçosa. 360 pp.
SANTOS SR and PEREIRA GM (2004) Comportamento da alface tipo americana sob diferentes tensões da água no solo, em ambiente protegido. Eng. Agríc. 24 (3) 569-577. https://doi.org/10.1590/S010069162004000300009

SELIM DAH, NASSAR RMA, BOGHDADY MS and BONFILL M (2019) Physiological and anatomical studies of two wheat cultivars irrigated with magnetic water under drought stress conditions. Plant Physiol. Biochem. 135 480-488. https://doi.org/10.1016/j. plaphy.2018.11.012

SILVA SS, DANTAS NETO J, AZEVEDO CAV, PEDROZA JP, PORDEUS R and REIS CF (2018) Phytomass of lettuce cultivars under water replenishment levels. Aus. J. Crop Sci. 12 (1) 74-80. https://doi.org/10.21475/ajcs.18.12.01.pne669

SOIL SURVEY STAFF (1999) Soil Taxonomy: A Basic System of Soil Classification for Making and Interpreting Soil Surveys. Natural Resources Conservation Service, Washington. 886 pp.

SOUZA AL, SEABRA S, DIAMANTE MS, SOUZA LHC and NUNES MCM (2013) Behavior of crisphead lettuce cultivars under tropical climate. Rev. Caatinga. 26 (4) 123-129.

SURENDRAN U, SANDEEP O and JOSEPH EJ (2016) The impacts of magnetic treatment of irrigation water on plant, water and soil characteristics. Agric. Water Manage. 178 21-29. https://doi. org/10.1016/j.agwat.2016.08.016

TOLEDO EJL, RAMALHO TC and MAGRIOTIS ZM (2008) Influence of magnetic field on physical-chemical properties of the liquid water: Insights from experimental and theoretical models. J. Molec. Struct. 888 (1-3) 409-415. https://doi.org/10.1016/j.molstruc.2008.01.010

TURINI T, CAHN M, CANTWELL M, JACKSON L, KOIKE S, NATWICK E, SMITH R, SUBBARAO K and TAKELE E (2011) Iceberg Lettuce Production in California. University of California Agriculture and Natural Resources, Davis. 6 pp.

UL HAQ Z, IQBAL M, JAMIL Y, ANWAR H, YOUNIS A, ARIF M, FAREED MZ and HUSSAIN F (2016) Magnetically treated water irrigation effect on turnip seed germination, seedling growth and enzymatic activities. Inf. Processing Agric. 3 (20) 99-106. https://doi. org/10.1016/j.inpa.2016.03.004

URBANO VR, MENDONÇA TG, BASTOS RG and SOUZA CF (2017) Effects of treated wastewater irrigation on soil properties and lettuce yield. Agric. Water Manage. 181 108-115. https://doi.org/10.1016/j. agwat.2016.12.001

VALERIANO TTB, SANTANA MJ DE, MACHADO LJM and OLIVEIRA AF (2016) Alface americana cultivada em ambiente protegido submetida a doses de potássio e lâminas de irrigação. Irriga. 21 (3) 620-630. https://doi.org/10.15809/irriga.2016v21n3p620-630

VALNIR JÚNIOR M, RIBEIRO FC, ROCHA JPA DA, LIMA SCRV, CARVALHO CM and GOMES FILHO RR (2017) Desenvolvimento de um software para o manejo da microirrigação. Rev. Bras. Agric. Irrig. 11 (2) 1324-1330. https://doi.org/10.7127/rbai.v11n200616

WANG Y, WEI H, LI Z (2018) Effect of magnetic field on the physical properties of water. Results Phys. 8 262-267. https://doi.org/10.1016/j. rinp.2017.12.022

YURI JE, MOTA JH, SOUZA RJ, RESENDE GM, FREITAS SAC and RODRIGUES JÚNIOR JC (2002) Alface americana - Cultivo comercial. Editora UFLA, Lavras. 51 pp.

YURI JE, RESENDE GM DE, MOTA JH, SOUZA RJ and RODRIGUES JÚNIOR JC (2004) Comportamento de cultivares e linhagens de alface americana em Santana da Vargem (MG), nas condições de inverno. Horticult. Brasil. 22 (2) 322-325. https://doi.org/10.1590/ S0102-05362004000200032

YURI JE, RESENDE GM DE, MOTA JH and SOUZA RJ (2006) Crisp head lettuce cultivars competition in southern of Minas Gerais. Rev. Caatinga. 19 (1) 98-102.

YUSUF KO and OGUNLELA AO (2017) Effects of deficit irrigation on the growth and yield of tomato (Solanum lycopersicum) irrigated with magnetised water. J. Environ. Res. Eng. Manage. 73 (1) 59-68.

ZLOTOPOLSKI V (2017) Magnetic treatment reduces water usage in irrigation without negatively impacting yield, photosynthesis and nutrient uptake in lettuce. Int. J. Appl. Agric. Sci. 3 (5) 117-122. https://doi.org/10.11648/j.ijaas.20170305.13 